\title{
USO DE LODOS DE DEPURADORA SOBRE SUELOS DE BAJA PRODUCTIVIDAD EN SANTA FE (ARGENTINA) ${ }^{1}$
}

\author{
Pilatti, M. A. ${ }^{2} ;$ Alesso, a. ${ }^{2}$; Felli, O. $^{2}$ \& Gasparotti, Y. e. ${ }^{3}$
}

\begin{abstract}
RESUMEN
Se evaluó el efecto de lodos de depuradora sobre la capacidad de productiva de los suelos de baja aptitud del centro-norte de Santa Fe, y sobre la producción de sorgo y avena. Se evaluaron dosis entre 0 y 38,5 y entre 0 y $109 \mathrm{Mg}$ de materia seca de lodo/ha, para sorgo y avena respectivamente, aplicadas previo a la siembra sobre un Natracualf típico. Se midió la respuesta en rendimiento y propiedades físicas y químicas del horizonte superficial. En ambos cultivos se observó respuesta positiva en comparación con el testigo. La salinidad moderada del lodo no afectó a los cultivos ya que se lavó con las precipitaciones. Se observó efecto positivo sobre las propiedades químicas y físicas del horizonte superficial, destacándose fósforo extraíble, calcio y magnesio intercambiable, nitrógeno total y carbono orgánico, estabilidad de agregados, e intervalo hídrico óptimo. El pH del suelo sólo tiende a mejorar con altas dosis.
\end{abstract}

Palabras claves: Natracualf; Intervalo hídrico óptimo,sorgo, avena.

\section{SUMMARY}

Using sewage sludge on soils with low productivity in Santa Fe (Argentina) The effect of sewage sludge on productive capacity of low aptitude soils (class IV or higher) from the center and north of Santa Fe, and on forage production of sorghum and oats was assessed. Before sowing of sorghum and oats, 0 to 38,5 and 0 to $109 \mathrm{Mg}$ of dry matter/ha of sludge was applied respectively, on a Typic Natracualf. Afterwards, along with forage yield, several chemical and physical soil properties were measured. For both crops, forage production was increased in response to the application of sludge. Moderate salinity levels of sludge has no effect on crop production because salts were washed quickly by rainfall. The amount of sludge applied was related positively to extractable phosphorus, exchangeable calcium and magnesium, total nitrogen, organic carbon, aggregate stability and least limiting water range. Soil $\mathrm{pH}$ was improved only at higher doses of sludge.

Key words: Natracualf, least limiting water range, sorghum, oats.

1.- Proyecto financiado parcialmente por CA+ID 2011 (UNL) 20/C409

2.- Cátedra de Edafología, Dpto. Ciencias del Ambiente Facultad de Ciencias Agrarias (UNL). Kreder 2805.

(3080) Esperanza, provincia de Santa Fe. Email: mpilatti@fca.unl.edu.ar

3.- Ing. Agr. Asesor particular.

Manuscrito recibido el 11 de junio de 2014 y aceptado para su publicación el 30 de julio de 2014 . 